\title{
Nuclear Graphites (II) : Mechanical Properties
}

\author{
Woong-Ki Choi ${ }^{1}$, Byung-Joo Kim ${ }^{1}$, Eung-Seon Kim ${ }^{2}$ Se-Hwan Chi ${ }^{2}$ and Soo-Jin Park ${ }^{3, \uparrow}$
}

\author{
${ }^{1}$ Jeonju Institute of Mechinery and Carbon Composites Palbokdong-2ga, 817, Jeonju, Jeollabuk-do 561-844, Korea \\ ${ }^{2}$ Dept. of Nuclear Hydrogen Project, KAERI, Daejeon 305-353,Korea \\ ${ }^{3}$ Dept. of Chemistry, Inha Univ., 253, Nam-gu, Incheon 402-751, Korea \\ ‘e-mail: sjpark@inha.ac.kr \\ (Received November 12, 2009; Accepted March 2, 2010)
}

\section{1. 서 론}

화석원료의 고갈에 대비한 수소생산용 원자로건설에 대한 관심이 전세계적으로 높아지고 있다. 원자로를 이용한 수소생 산은 고온으로 수증기를 가열하여 열분해를 통해 수소를 생산 하는 방식으로 기존 원자로가 발생하는 $800^{\circ} \mathrm{C}$ 보다 높은 $1000^{\circ} \mathrm{C}$ 부근의 온도를 요구하고 있어 고온가스냉각반응로에 대한 다양한 형태의 원자로가 거론이 되고 있다. 따라서 이에 적합한 새로운 개념을 갖는 원자로에 대한 연구가 진행되고 있고 이와 같이 원자로 사용 재료에 대한 연구 또한 진행되고 있다. 고온가스냉각반응로에 사용되는 재료는 고온물성과 중 성자에 안정한 재료가 요구되며 흑연은 이에 부합하는 최고의 재료로 원자로 내부와 지지체 등에 상당량이 사용이 예상된다. 흑연은 핵분열시 발생하는 중성자에 견디는 능력이 여타 재료 에 비해 매우 탁월하고 반응속도를 늦쳐주는 감속재, 그리고 중성자를 내부로 제한하는 반사체로 매우 효과적인 재료이 다 [1-3].

그러나 원자로 내에서 사용되는 흑연의 경우 고온 및 중성 자 조사에 의한 체적변화로부터 발생되는 응력에 의해 건전성 및 안전성이 결정된다고 보고되고 있다.

흑연이 중성자에 노출되면 수축이 일어나고 중성자에 노출 되는 시간이 길어지면 수축하다가 팽창하기 시작한다 [4]. 원 자로 내에서의 흑연의 수축은 원자로의 설계를 통해 용이하게 수축에 의한 응력의 발생을 제어할 수 있으나 팽창에 의한 응 력은 제어하기가 용이하지 않기 때문에 원자로 운영에 있어서 치명적이다. 이러한 이유로 원자로에 사용하는 흑연의 수명은 중성자 조사에 의해 수축에서 팽창으로 변환하는 시점까지를 흑연의 운영수명으로 잡고 있다 [5].

흑연의 산화는 가스상반응과 표면반응 그리고 기타반응 등 여러 형태로 일어나는데 대부분의 산화는 흑연의 표면반응에 해당이 된다. Kawakami [6] 등에 의하면 흑연은 온도영역에 따라 $600^{\circ} \mathrm{C}$ 부근의 chemical regime, $700 \sim 900^{\circ} \mathrm{C}$ 부근의 inpore chemical regime, 그리고 $1000^{\circ} \mathrm{C}$ 이상의 mass trasfer controled regime으로 구분되어 산화가 일어난다고 보고하고 있으며 chemical regime의 산화는 흑연블럭 표면과 내부의 산 화가 동시에 일어나고 in-pore chemical regime에서 산화는 표 면부근이 내부의 산화보다 활발이 일어나며 mass trasfer controled regime은 대부분의 산화가 표면에서 일어난다고 보 고하고 있다. 흑연의 산화 원리는 원자로의 가동 중에 흑연이 노출되는 온도영역에 해당 되어 원자로의 안정성과 직접관련 이 있기 때문에 원자로에 사용하는 흑연의 수명을 결정 짖는 또 하나의 중요한 고려인자가 된다 [7,8].

원자로급 흑연의 중성자에 의한 물성변화의 경우 널리 연구 가 되어 있으나 산화에 대한 물성변화는 국내는 물론하고 세계 적으로도 연구가 활발하지 않은 편이기 때문에 원자로급 흑연 의 산화에 대한 물성 변화 연구는 원자로 설계 및 가동안정성 에 매우 중요하다. 또한 현재 원자로급 흑연의 기계적 성질에 대한 연구의 경우 상온을 중심으로 이루어 졌으나, 실제 원자 로 가동조건인 $900^{\circ} \mathrm{C}$ 이상의 고온에서는 이루어 지지 않고 있 다. 따라서 산화 및 고온에서의 원자로급 흑연 물성 평가 데이 터는 실제 원자로 가동 조건의 기본 데이터로 활용되고, 초고 온 가스로 건설의 디자인 데이터로 사용될 것으로 판단된다 [9].

\section{2. 본 론}

\section{1. 원자로급 흑연의 특징 및 요구되는 특성}

흑연은 열전도도가 좋고, 녹는점이 매우 높으며, 비산화 분 위기에서 화학적으로 매우 안정하기 때문에 기계적 성질이 감 소하지 않는다. 또한 중성자 감속효과가 매우 우수하다. 이런 특성들로 인해 흑연은 VHTR 노심 내에서 구조재에 이용될 뿐만 아니라 감속재, 반사재의 역할을 동시에 수행하게 된다. 그러나 원자로에 사용되기 위해서는 일반적으로 사용되고 있 는 흑연과는 달리 몇 가지 특수한 요건들을 만족시켜야 한다 $[10,11]$.

초고온가스로에 이용되기 위한 흑연의 요구되는 특성은 다 음과 같다.

(1) 방사능 단위 면적당 탄소 원자의 개수에 따라 결정이 되 어지기 때문에 반사재로써 사용하기 위해 흑연의 밀도는 최소 $1.70 \mathrm{~g} / \mathrm{cm}^{3}$ 이상이어야 한다. (1.75에서 1.80 정도 권장)

(2) 중성자의 효율을 높이기 위해 중성자 흡수 단면적은 약 $4 \mathrm{mbarns}$ 정도를 가져야 하며, 중성자 흡수율이 아주 높은 붕 소는 $3 \mathrm{ppm}$ 이하로 제한 된다. 
(3) 방사선 동위원소로 변할 수 있는 $\mathrm{Li}, \mathrm{B}, \mathrm{Co}$ 와 처리비용 이 높은 $\mathrm{N}, \mathrm{Cl}, \mathrm{Ni}$ 등의 불순물들은 최소화되어야 한다.

(4) 조사에 의한 체적변화로 인해 열팽창율은 20 에서 $120^{\circ} \mathrm{C}$ 사이에서 $4 \times 10^{-6} / \mathrm{K}$ 에서 $5.5 \times 10^{-6} / \mathrm{K}$ 까지 유지되어야 하며 열 전도도는 상온에서 $100 \mathrm{~W} / \mathrm{m} \cdot \mathrm{K}$ 보다 높아야 한다.

(5) Dynamic Young's Modulus는 $12 \mathrm{Kn} / \mathrm{mm}^{2}$ 이하로 유지되 어야 한다.

원자로급 흑연은 산화를 촉진시키거나, 중성자 효율을 떨어 뜨릴 수 있는 불순물을 최소화 시켜 매우 순도가 높고, 중성 자 조사에 의한 체적변화나 열 퍙창 등에 의한 응력을 줄이기 위해 상당히 높은 기공률을 가지고 있으며 원자로 내에서 고 온 및 중성자 조사에 의한 체적변화를 흡수하기 위해 등방적 성질 또한 가지고 있다.

\section{2. 원자로급 흑연의 미세구조}

원자로급 흑연의 미세구조는 크게 충진재인 코크 입자들과 바인더 상 그리고 기공으로 이루어져 있다. 바인더 상에 의해 결합되어 있는 코크 입자들은 바인더 상보다 입자크키가 크고 강도가 높으며, 비등방적 성질을 가지고 있다. 이들 코크 입자 들은 basal 면들이 약하게 결합되어 있기 때문에 여기를 따라 쉽게 미세균열들이 발생하게 된다. 따라서 낮은 응력 하에서 도 쉽게 균열이 전파되거나 균열의 시작점이 되기도 한다. 반 면, 코크 입자들은 바인더 상보다 강도가 높고, 길쭉한 봉의 형태를 띄고 있기 때문에 균열과 만나더라도 깨지지 않고 진 행을 막거나, 균열면의 열림을 막아주기도 한다 [12]. 바인더 상은 $100^{\circ} \mathrm{C}$ 정도의 낮은 온도에서 유동성을 띄는 콜타르 피 치(coal-tar pitch)로 부터 만들어 지며, 이로 인해 성형과 혼합 을 쉽게 할 수 있다.

바인더 상은 도메인(domain)과 모자익(mosaic) 구조로 나눌 수 있으며, 도메인은 바인더 상이 $100 \mathrm{~nm}$ 이상 잘 배열 되어 있는 영역으로 파괴응력 이하에서 쉽게 파괴가 발생할 수 있 다. 모자익 구조는 $10 \mathrm{~nm}$ 이하로 바인더상이 배열되어 있는 구조로서 파괴응력 근처에서 파괴가 일어난다. 기공은 크게 두 가지 역할을 하는데, 첫 번째로는 기공 주위에 국부적으로 집 중된 응력과 가한 응력장과의 상호작용으로 인하여 균열의 시 작을 쉽게 하며, 두 번째로는 기공주위의 응력장으로 인해서 진행하고 있는 균열을 기공 쪽으로 잡아 당겨 균열의 전파를 쉽게 한다 그러나 구형의 기공을 가지고 있는 흑연에서는 기 공들이 균열 끝에 집중된 응력을 분산시킴으로 인해 파괴인성 값을 조금 높이는 역할을 할 수가 있다 [13].

\section{3. 원자로급 흑연의 산화에 따른 물성변화}

\subsection{1. 원자로급 흑연의 활성화 에너지}

Fig. 1은 원자로급 흑연의 등급별 활성화 에너지를 나타낸 그래프로써, IG-11의 경우 3개 산화영역에서 활성화 에너지가 낮은 것이 관찰되었다. 그리고 $\mathrm{IG}-110, \mathrm{IG}-430$ 에 비해 표면반
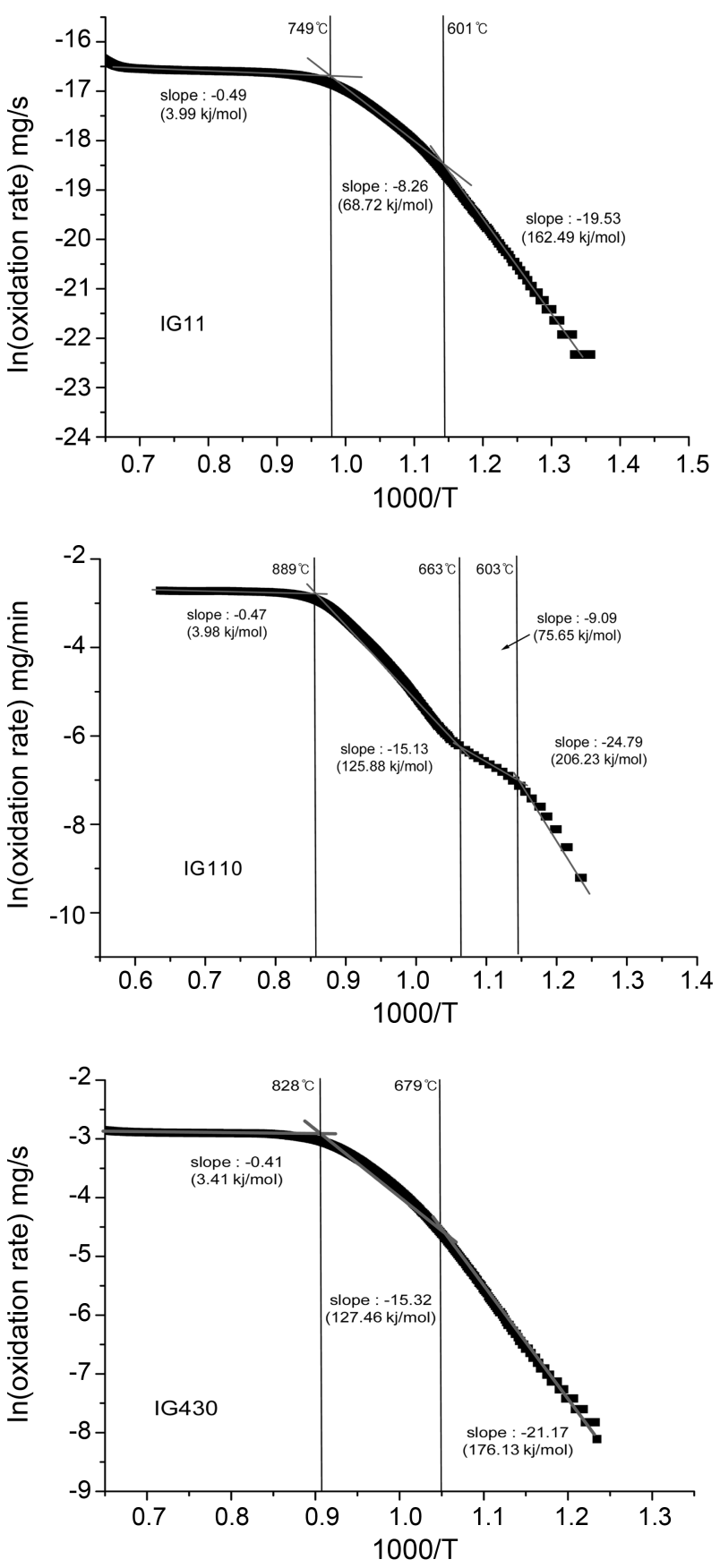

Fig. 1. 원자로급 흑연의 등급별 활성화 에너지 [14].

응영역이 약 $100^{\circ} \mathrm{C}$ 정도 낮은 온도인 $749^{\circ} \mathrm{C}$ 부터 나타났다. IG110 의 활성화 에너지를 변곡점으로 구분할 경우 IG-11과 IG430 에서 나타나지 않았던 $603 \sim 663^{\circ} \mathrm{C}$ 부근에서 활성화 에너지 가 낮은 영역이 짧게 관찰되었다.

$\mathrm{IG}-110$ 은 IG-11를 고순도화한 재료로써 IG-11에 비해 기계 적 물성이 약간 감소하는 경향이 관찰되었는데 이는 고순도화 하는 과정에서 흑연 내 불순물이 빠지면서 남게 되는 미세한 기공으로 인해 기계적 물성을 감소시키는 것으로 보이며, 조 


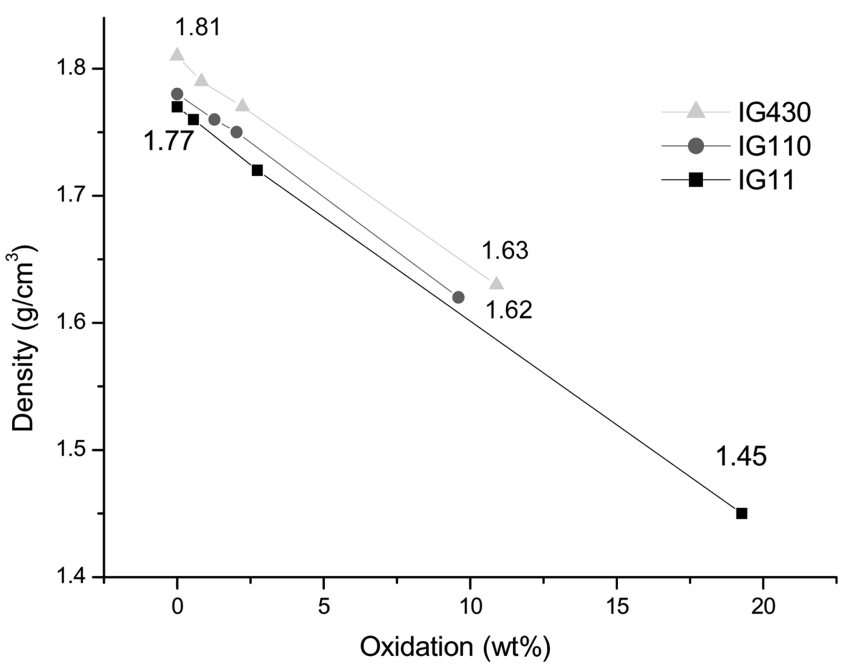

Fig. 2. 산화율에 따른 원자로급 흑연의 밀도의 변화 [14].

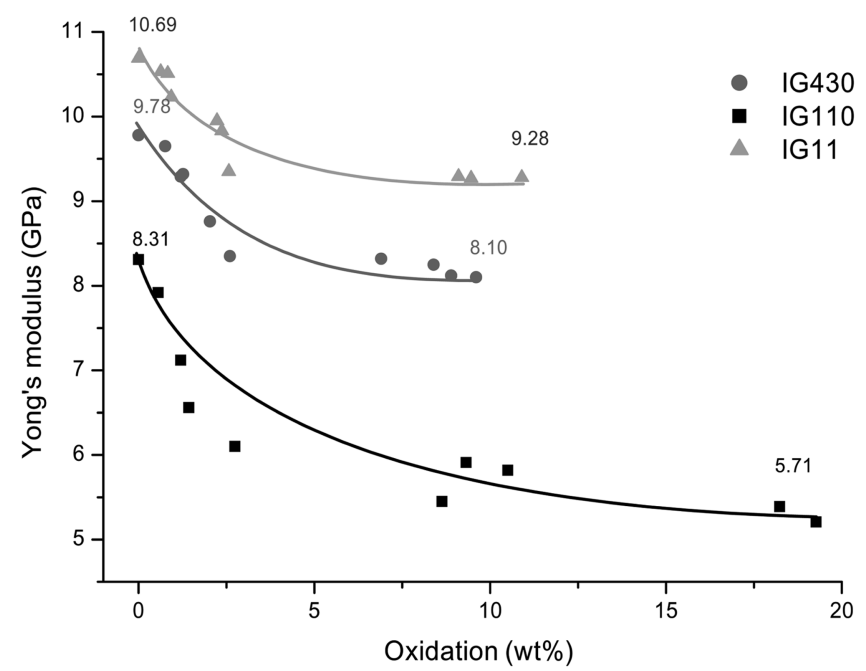

Fig. 3. 산화율에 따른 원자로급 흑연의 탄성률의 변화 [14].

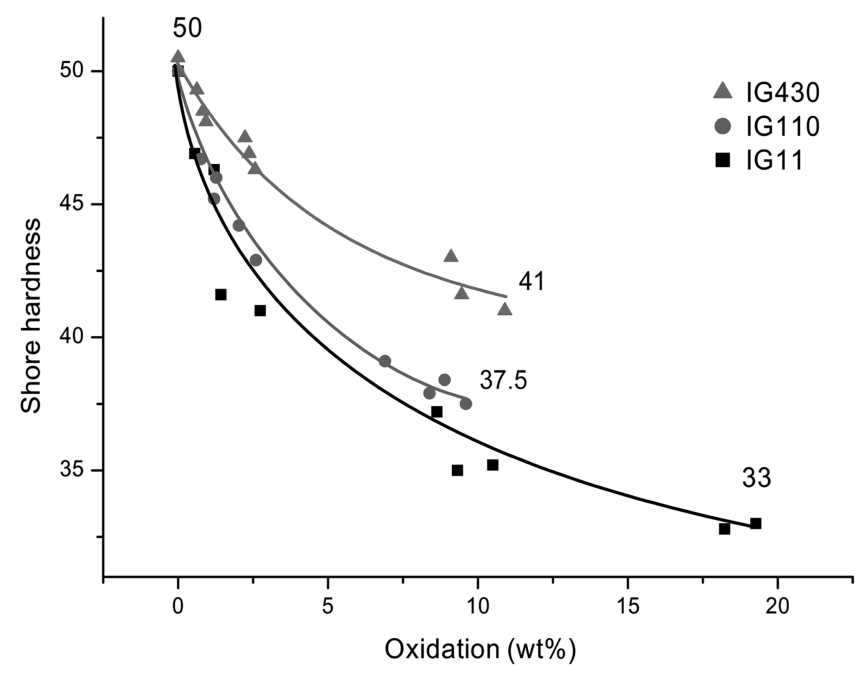

Fig. 4. 산화율에 따른 원자로급 흑연의 쇼아경도의 변화 [15].
직에 남게 되는 미세한 기공이 확산반응과 화학반응의 경계에 서 일시적으로 산화를 촉진하게 되어 활성화 에너지가 낮아진 것으로 판단된다 [14].

2.3.2. 원자로급 흑연의 산화에 따른 탄성률, 쇼아경도, 밀도 의 변화

원자로급 흑연이 산화율에 따라 탄성률, 쇼아경도, 밀도의 변화를 측정하여 산화에 의해 물성값의 변화가 어떻게 변하는 지 측정하였으며 그 결과를 Figs. 2 4에 각각 나타내었다.

산화율이 증가함에 따라 밀도값은 일정하게 반비례하며 감 소하였으며, 이것은 흑연이 $600^{\circ} \mathrm{C}$ 부근에서 산화될 경우 흑연 의 활성화 에너지가 상대적으로 높아 산소와 탄소간의 반응이 어렵기 때문에 산화속도가 낮을 뿐만 아니라 산소가 시편 표 면에서 반응에 의해 전량 소모되지 않고 흑연 내부에 도달함 에 따라 시편내부와 표면이 동일하게 산화 됨에 따라 형상의 변화 동반되지 않기 때문에 밀도 값은 산화율에 직선적으로 반비례하여 감소하게 된 것으로 판단된다.

산화율이 증가함에 따라 탄성률과 쇼아경도 값은 지수함수 적으로 감소하였으며, 이는 G B. Neighbour, P.J. Hacker가 연 구한 산화율에 따라 압축강도가 지수함수적으로 감소한 결과 와 같은 경향을 보이고 있다. 탄성률은 산화율 $2.5 \%$ 부근까지 큰 폭으로 감소가 진행되었으며, 산화율 $2.5 \%$ 부근의 탄성률 이 $\mathrm{IG}-11$ 의 경우는 $28 \%, \mathrm{IG}-110$ 은 $15 \%, \mathrm{IG}-430$ 은 $13 \%$ 로 각 각 감소되었다.

쇼아경도 값의 경우 산화율 $10 \%$ 부근까지 큰 폭의 감소가 진행되었으며 산화율 $10 \%$ 부근에서 $\mathrm{IG}-11$ 의 경우 $30 \%$, IG110 는 $25 \%, \mathrm{IG}-430$ 은 $18 \%$ 로 각각 감소되었다. 이러한 감소는 Knudsen이 제시한 지수함수 식과 일치하는 결과를 나타내고 있다.

$$
\mathrm{A}=\mathrm{A}_{0} \exp (-\mathrm{bx})
$$

위의 식은 지수함수 식으로 여기서 $\mathrm{A}$ 는 물성치, $\mathrm{b}$ 는 지수, $\mathrm{x}$ 는 산화율, $\mathrm{b}$ 는 재료에 따른 고유 상수를 나타낸다 [15].

\subsection{3. 원자로급 흑연의 산화에 따른 마찰거동}

Fig. 5은 산화율에 따른 마찰거동을 나타낸 것으로 마찰계 수의 변화를 통해 관찰하였다. 마찰계수의 경우 마찰이 시작 되면서 낮은 값을 나타내다가 마찰이 진행되면서 마찰계수의 값이 증가하였으며, 이러한 결과는 마찰에 의해 흑연 표면의 입자들이 떨어져 나가면서 표면이 거칠어지기 때문에 마찰계 수가 증가하는 것으로 판단된다. 산화율이 작을 때는 전반적 으로 마찰계수 값이 낮아짐이 관찰되었고 산화율이 증가함에 따라 마찰계수 값이 증가하였다. 이러한 결과는 산화에 의해 흑연조직이 물러져 적은 산화량에서는 마찰시 잘 부서져 마찰 계수가 낮아졌고, 산화량이 증가하면 시편조직이 심하게 손상 되어 마찰시 뜯김과 파임 현상이 발생 하여 마찰거동이 불안 정하여 오히려 마찰계수 값을 상승시킨 것으로 판단된다.

Fig. 6은 산화 전후의 마찰표면을 관찰한 사진으로서 산화 

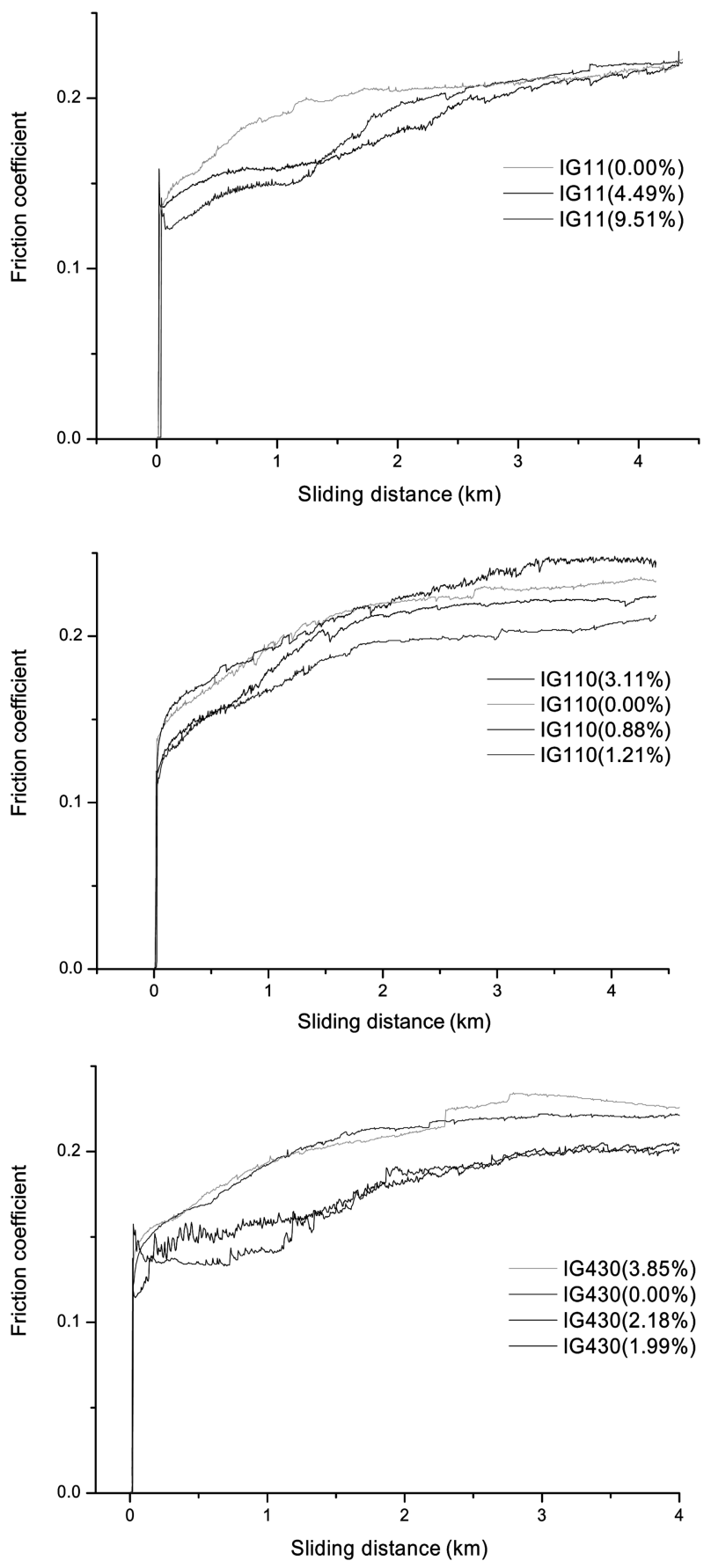

Fig. 5. 산화율에 따른 원자로급 흑연의 마찰거동의 변화 [15].

전 마찰표면은 전반적으로 균일하게 마찰이 이루어졌음을 확 인할 수 있으며, 산화 후 시편의 마찰표면은 산화점(oxidation pit)이 관찰되는 등 손상된 표면을 관찰 할 수 있다.

IG-11의 마찰면의 사진에서는 IG-110에 비해 산화점이 매우 크게 나타났으며, 이는 $600^{\circ} \mathrm{C}$ 부근에서 화학반응에 의해 산화 가 진행되어지기 때문에 시편이 가지고 있는 불순물, 결함 등 에 의해 산화가 촉진되기 때문으로 판단된다 [15].
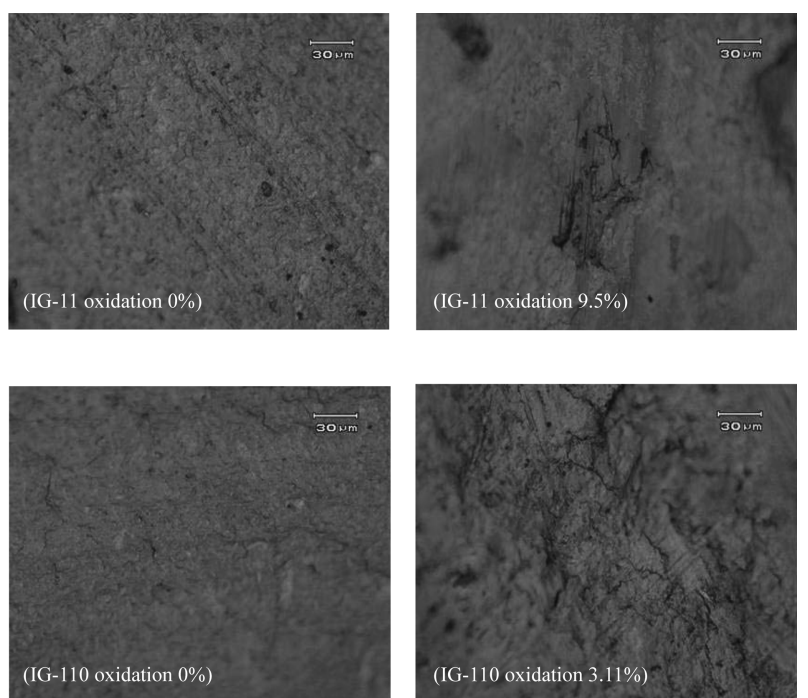

Fig. 6. 원자로급 흑연의 산화전 · 후의 마찰 표면의 SEM 사 진 [15].

\section{4. 원자로급 흑연의 고온 강도 특성 및 파괴특성 평가}

원자로급 흑연의 파괴인성에 대한 산화 효과 연구는 초고온 가스로의 디자인 설계나 구조물 안전에 대한 해석을 위해 중 요한 데이터로 사용된다. 왜냐하면 흑연은 사고시나 가동 중 외부에서 산소의 유입에 의해 산화가 될 것이고 이러한 산화 는 흑연의 기계적 성질을 저하시키게 되기 때문이다. 현재까 지 많은 연구자들에 의해 흑연의 강도와 파괴인성에 대한 산 화효과 연구는 많이 진행되어 왔다. 예를 들자면 흑연이 $10 \%$ 산화될 때 $50 \%$ 정도의 파괴인성과 강도 값이 감소된다고 보 고되고 있다. 비록 강도나 파괴 인성의 관계는 수많은 연구자 들에 의해 연구되었지만 아직 산화 후에 고온에서 강도나 파 괴인성 테스트를 한 데이터는 부족한 실정이다.

\subsection{1. 파괴역학의 기초}

현재의 파괴역학은 어떤 값으로서의 임계치, 즉 파괴인성치 의 물리적인 의미, 그 파괴과정 또는 파괴기구에 대한 물리적 인 해석을 갖고 있지 않다. 다만 파괴의 기준으로서의 파괴인 성치가 재료고유의 물성치로 이용되었기 때문에 파괴역학은 구조재의 강도설계, 수명 예측에 공학(engineering) 으로서 쓰 일 수 있는 것이다.

임의의 형상을 갖는 탄성체가 외부하중 $(\mathrm{P})$ 를 받고 있을 때, 그 중에 존재하는 예리한 균열 (길이 $2 \mathrm{a}$ )의 주변에서 응력분 포를 생각해보면 균열선단의 응력집중 (stress concentration)때 문에 파괴하중(임계하중) $\mathrm{P}_{\mathrm{C}}$, 또는 파괴응력 $\sigma_{\mathrm{c}}$ 는 이 균열에 의해 지배되며, 그 크기가 클수록 이 탄성체의 강도가 저하하 는 것을 일상의 경험으로부터도 알 수 있다. 선형 파괴역학의 가장 중요한 관계식으로서, 평균 균열 (equilibrium crack)에 대 한 임계하중 $\mathrm{P}_{\mathrm{C}}$ 를 다음과 같이 식으로 표현할 수 있다. 
$\mathrm{P}_{\mathrm{C}}=\mathrm{P}_{\mathrm{C}}\left(\mathrm{a}, \mathrm{D}, \mathrm{K}_{\mathrm{C}}\right)$

여기서 $\mathrm{D}$ 는 탄성체의 특성크기(폭, 높이, 두께 등)이며 $\mathrm{K}_{\mathrm{c}}$ 는 임계응력확대계수(critical stress intensity factor)이다. 응력확 대계수 $\mathrm{K}$ 가 외부하중에 비례하는 사실로부터 위의 식을 다음 과 같이 바꾸어 쓸 수 있다.

$\mathrm{P}_{\mathrm{C}}=\mathrm{K}_{\mathrm{C}} \cdot \mathrm{f}_{\mathrm{P}}(\mathrm{a}, \mathrm{D})$

위의 식을 응력표현으로 표시하면 아래와 같은 식이 된다.

$$
\sigma_{\mathrm{C}}=\mathrm{K}_{\mathrm{C}} \cdot \mathrm{f}_{\mathrm{P}}(\mathrm{a}, \mathrm{D})
$$

함수 $\mathrm{f}_{\mathrm{P}}(\mathrm{a} . \mathrm{D})$ 와 $\mathrm{f}_{\sigma}(\mathrm{a} . \mathrm{D})$ 는 탄성체 및 그 균열의 형상과 크 기가 응력확대계수에 미치는 영향을 기술하는 형상인자(shape factor)이다. 이 임계응력확대계수 $\mathrm{K}_{\mathrm{C}}$ 는 균열선단의 응력상태, 즉 평면응력(plane stress)인가 또는 평면변형(plane strain)인가 에 강하게 의존하고 있기 때문에 일반적으로 $\mathrm{K}_{\mathrm{C}}$ 를 균열저항 성을 나타내는 물성치로서 채용할 수는 없다.

균열선단의 응력 변위의 구속조건이 다르며 소성변형이 주 인 금속재료의 경우 평면응력에 대한 $\mathrm{K}_{\mathrm{C}}$ 는 보통 평면변형에 대한 것보다도 크다. 평명변형에서의 3축 응력상태가 균열선 단에서의 소성변형을 억제하기 때문에, 평면변형 $\mathrm{K}_{\mathrm{C}}$ 의 값이 작아지게 된다. 이 3축 응력상태는 탄성체의 두께가 어느 정 도 이상이 되면(평면 변형 상태) 그 두께에 의존하지 않게 된 다. 따라서 평면변형 $\mathrm{K}_{\mathrm{C}}$ 는 시편형상에 의존하지 않는 물성치 로서의 파괴저항성 parameter가 된다. 이 물성치로서의 $\mathrm{K}_{\mathrm{C}}$ 를 $\mathrm{K}_{\mathrm{IC}}$ 로 표현하며, 이것을 파괴인성치(fracture toughness)로서 정 의하기도 한다. $\mathrm{K}_{\mathrm{IC}}$ 는 각종의 응력상태에 대응하는 $\mathrm{K}_{\mathrm{C}}$ 중에서 가장 작은 값을 갖기 때문에 구조물의 설계에 $\mathrm{K}_{\mathrm{IC}}$ 를 사용하는 것은 보통 안전측면의 설계가 되는 점에서도 중요하다 [16-19].

\subsection{2. 파괴인성의 측정}

현재 파괴인성치의 평가에 사용할 수 있는 다양한 측정법이 있으나 [20-24] 이 중 취성재료의 파괴인성치 측정법으로는 연 구목적, 재료의 파괴거동, 그 미세구조등에 주안점을 두어 최 적의 평가법을 선택할 필요성이 있다. 파괴인성치의 측정에 주 의해야 할 요건은 다음과 같다.

(1) 시험편의 크기: 평면변형 상태를 보증하기 위해 균열길 이 및 시편두께, ligament 길이는 모두 평형균열에 대한 process zone의 크기에 비하여 충분히 커야 한다. 또한 최대 소결입경 에 비해서 시험편의 크기, 균열길이 등을 통계적으로 충분한 크기로 선택하는 것도 중요하다.

(2) 노치, 균열의 기하형상: 형상인자가 이미 알려져 있지 않 다면 원리적으로는 임의의 기하형상을 갖는 노치 또는 균열을 사용하여 파괴인성치를 평가할 수 있으나, 시험편 가공비, 균 열도입의 용이성 등의 이유에 의해 거시노치와 압자에 의해 도입된 표면 미세균열기하 형상이 취성재료의 파괴인성치 평 가법으로서 현재 널리 사용되고 있다.

(3) 균열선단의 곡률반경: 거시노치는 보통 다이아몬드 날에
의해 가공되어 진다. 따라서 곡률반경 $\rho$ 는 사용한 다이아몬드 날 두께의 반값 정도로 생각할 수 있다. 그러나 선형파괴역학 에서는 $\rho=0$ 인 균열을 상정하기 때문에, 노치 선단의 곡률반경 은 평가되는 파괴인성치에 강하게 영향을 미치는데, $\rho$ 의 감소 와 함께 겉보기의 파괴인성치는 감소하며, 취성 재료의 미세 조직에 의존하는 특성 곡률반경 $\left(\rho_{\mathrm{c}}\right)$ 이하에서는 일정치, 즉 진 정한 파괴인성치에 가까워 지는 것으로 알려져 있다 [25].

(4) Peak 하중에서의 파괴인성 시험 평가: 완전 탄성체의 하 중-변위곡선 (P-v 곡선)은 균열이 진전을 개시하는 임계 상태 까지 선형의 관계에 있으며, 임계하중 $\left(\mathrm{P}_{\mathrm{C}}\right)$ 은 peak하중 $\left(\mathrm{P}_{\max }\right)$ 와 일치한다. 이와 같은 이상탄성체에서는 $\mathrm{P}_{\max }$ 를 이용하여 파괴 인성치를 결정하는 것에 아무런 문제가 없다. 그러나 흑연과 같은 상승형의 R-곡선 때문에 $\mathrm{P}_{\max }$ 보다 낮은 하중 level에서부 터 균열의 진전이 시작된다. 즉 $\mathrm{P}_{\mathrm{C}}<\mathrm{P}_{\max }$ 가 성립하여 $\mathrm{P}_{\max }$ 까지 의 안정균열의 성장에 의해 P- $v$ 곡선에는 겉보기의 의소성이 관찰되며 이러한 경우 $\mathrm{P}_{\max }$ 로 부터 파괴인성치를 구할 수 없다.

(5) 고온측정: 고온에서의 재특성 특히, 고온에서의 파괴인성 치의 실험적 평가는 극히 중요하다. 고온에서의 파괴인성치 측 정법중 가장 적합한 측정은 편측 노치부 3점 꺽임 시험법 (single edge-notched 3-point bend bar)이다.

\subsection{3. 원자로급 흑연의 고온 파괴인성}

파괴인성과 강도와 같은 원자력급 흑연의 기계적 성질은 고 온에서 증가된다고 보고되고 있다. Fig. 7은 4가지 흑연 (IG11 ,IG-110, NBG-17, NBG-18)의 파괴인성의 결과를 나타낸 것으로써 IG-110이 상온에서 보다 고온 약 $600^{\circ} \mathrm{C}$ 에서 약 $14 \%$ 정도 파괴인성 값이 증가하였으며 $700^{\circ} \mathrm{C}$ 고온에서도 $600^{\circ} \mathrm{C}$ 와 마찬가지로 비슷한 경향을 가지는 것으로 나타났다. 그러나 $\mathrm{NBG}$ 흑연의 경우 IG 계열의 흑연보다 grain 사이즈가 사이즈 가 크기 때문에 좀 더 큰 편차를 보였으며 특히 가장 큰 grain 사이즈를 가지고 있는 NBG-18이 가장 큰 편차를 보이는 것 으로 관찰 되었다 [9].

\subsection{4. 고온 파괴인성 및 고온 강도 증가 기구}

원자로급 흑연은 흑연화 온도 $\left(2000 ~ 3000^{\circ} \mathrm{C}\right)$ 에서 cooling 시켜서 제조가 되는데, 이때 Mrozowski crack이 cooling 하는 동안 a축과 $\mathrm{c}$ 축의 열팽창 계수가 다르기 때문에 생성된다. 상 온에서는 grain이 수축되어 있는 상태이고, 바인더 상에 인장 응력이 걸려 있게 된다. 하지만 고온에서는 grain이 열에 의해 팽창되고 바인더 상의 인장응력이 압축응력으로 변하게 된다. 바인더 상의 압축응력은 크랙이 전전 할 때 방해하는 역할을 함으로써 파기인성 및 강도가 증가된다고 판단된다. Fig. 8은 흑연의 Mrozowski crack을 나타낸 그림이고 Fig. 9은 고온에 서 원자력급 흑연의 파괴인성 및 강도 증가 기구를 나타낸 그 림이다.

2.4.5. 파괴 인성에 대한 산화 효과 기구 원자로급 흑연의 파괴인성은 포어 사이즈와 접근성에 의존 

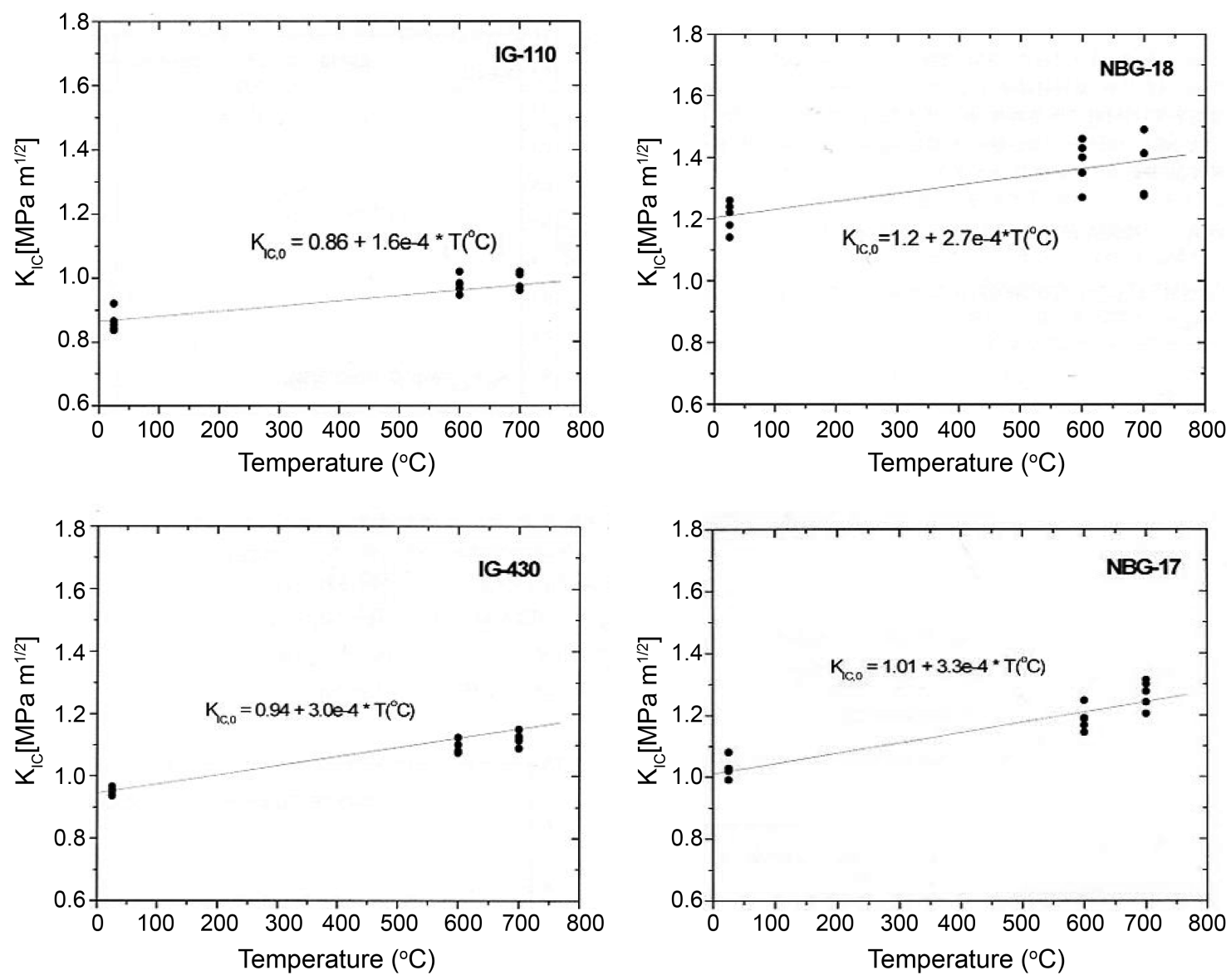

Fig. 7. 원자로급 흑연(IG-11 ,IG-110, NBG-17, NBG-18)의 온도에 따른 파괴인성의 결과 [9].

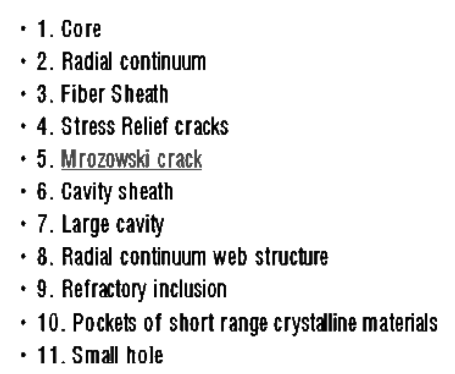

Fig. 8. 원자로급 흑연의 Mrozowski crack.

한다. 포어 사이즈와 포어의 위치에 따라 blunting 효과에 의 해 파괴인성 값은 강화되기도 하고 포어의 접근성에 의해 약 화 되기도 한다. 원자로급 흑연에 산화가 일어나면 바인더 상 이 우선적으로 산화가 되고 바인더 상의 포어가 증가함으로써 포어끼리 접근성이 커지거나 포어끼리 연결이 된다. 크랙은 포 어를 따라서 쉽게 진전하기 때문에 흑연의 산화가 진행됨에 따라서 파괴인성 값은 지수 함수적으로 감소할 것이라고 판단 된다.

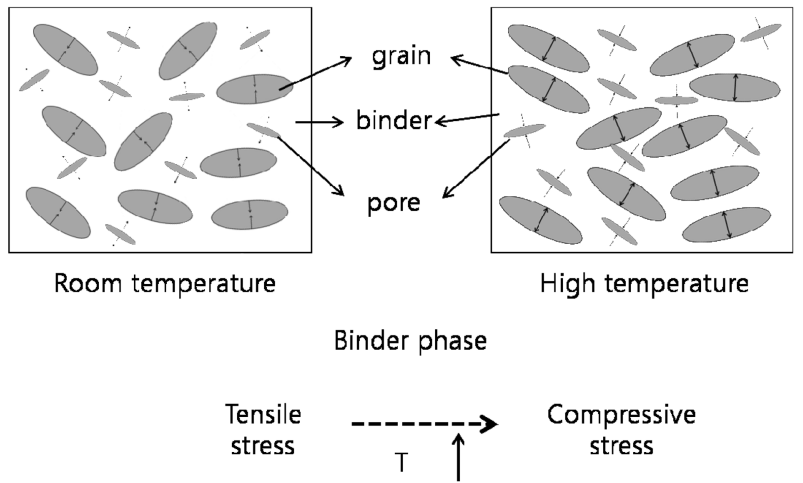

Fig. 9. 고온에서 원자로급 흑연의 파괴인성 및 강도증가 기구.

3. 결 론

흑연은 결합력이 큰 기저면을 따라 우수한 열전도도 및 전 기전도도를 나타내고 화학적으로도 매우 안정하여 화학, 전기 전자, 기계, 자동차, 원자로등에 널리 사용되고 있으며 고온가 스로에 서는 감속재, 반사체 및 지지체 등에 사용된다.

그러나 흑연은 원자로 가동 중 온도구배와 원자로 내부 압 
력, 조사에 의한 체적 변화등으로부터 발생하는 내부 압력, 그 리고 자중 등에 의해 지속적으로 응력이 가해지게 된다. 따라 서 이런 응력 상태에 놓여 졌을때 흑연의 건전성 및 안전성을 평가하기 위해서는 기계적 물성의 평가는 필수라 할 수 있다.

현재 원자로급 흑연의 기계적 성질에 대한 연구는 주로 상 온을 중심으로 이루어 졌으나, 실제 원자로 가동 조건인 $900^{\circ} \mathrm{C}$ 이상의 고온에서는 이루어 지지 않고 있으며, 또한 산화에 전. 후에 대한 물성 평가에 대한 연구도 활발하지 않은 편이다. 흑연 기계적 물성 평가 데이터는 실제 원자로 가동 조건의 기 본 데이터로 활용되고, 초고온 가스로 건설의 디자인 데이터 로 사용될 것으로 판단되며 또한 원자로 구조 건정성 평가에 도 중요하게 사용될 것으로 판단된다. 따라서 실제 가동조건 을 고려한 기계적 성질들의 평가는 설계 및 재료의 선정을 위 한 필수 핵심항목으로 국내 기술의 축적이 요구될 것으로 판 단된다.

\section{References}

[1] Hopkinson, K. L.; Marsden, B. J.; Dundulis, G.; Kopustinskas, V.; Liaukonis, M.; Augutis, J.; Uspuras, E. Nucl. Eng. Des. 2003, 223, 117.

[2] Menachem, C.; Wang, Y.; Flowers, J.; Peled, E.; Greenbaum, S. G. J. Power Sources 1998, 76, 180.

[3] Felix, C.; Difilippo, Ann. Nucl. Energy 2004, 31, 135.

[4] Neighbour, G. B.; Hacker, P. J. Materials Letters 2001, 51, 307.

[5] Kurumada, A.; Oku, T.; Harada, K.; Kawamata, K.; Sato, S.; Hiraoka, T.; McEancy, B. Carbon, 1997, 35, 1157

[6] Kawakami, H. Tanso 1986, 124, 26.

[7] Xiaowei, L.; Jean-Charles, R.; Suyuan, Y. Nucl. Eng. Des. 2004, 227, 273.

[8] Loren Fuller, E.; Okoh, J. M. J. Nucl. Mater. 1997, 240, 241.
[9] 노재승; 장창희; 김민우; 권지현; 서승국; 전호연; 김경화 “원자력급 흑연의 고온강도 및 Emissivity 특성 평가", KAERI/CM-1128 2008,17.

[10] Bilot, P.; Seran, J. L.; Calbrillat, M. T.; Burlet, H.; Terlain, A.; Bonal, J. P. "CEA R\&D Program on Structural Materials for Future Gas-Cooled Nuclear Systems", Basic Studies in the Field of High-Temperature Engineering, Third Information Exchange Meeting, Japan, 2003.

[11] Haag, G.; Mindermann, D.; Wilhelmi, G; Persicke, H.; Ulanmer, W. J. Nucl. Mater. 1990, 171, 41.

[12] Ouagne, P.; Neighbour, G B.; McEnaney, B. J. Phys. DAppl. Phys. 2002, 35, 927.

[13] Pickup, I. M.; McEnaney, B.; Cooke, R. G. Carbon 1986, 24, 535.

[14] 조광현; 김경자; 임연수; 정윤중; 지세환 J. Korean Ceramic Society 2006, 43, 838.

[15] 김경자; 조광연; 정영근; 류도형; 장정호 “수소생산용 초 고온가스로 예비개념설계 및 요소기술개발”, KAERI/ CM-906, 2005.

[16] Ioka, I.; Yoda, S.; Konishi, T. Carbon 1990, 28, 879.

[17] Jin, F. L.; Park, S. J. Mater. Sci. Eng. A-Struct. Mater. Prop. Microstruct.Process 2008, 478, 402.

[18] Park, S. J.; Seo, M. K.; Lee, J. R. Compos. Interfaces 2006, 13, 249.

[19] Park, S. J.; Jeong, H. J.; Nah, C.W. Mater. Sci Eng. A-Struct.Mater. Prop. Microstruct. Process 2004, $385,13$.

[20] Evans, A. G. Fract. Mech. Ceram. 1974, 1, 17.

[21] Shih, T. T. Opoku, J. Eng. Fract. Mech. 1979, 12, 479.

[22] Munz, D. Fract. Mech. Ceram. 1983, 6, 1.

[23] Freiman, S. W. Idid 1983, 6, 27.

[24] Freiman, S. W. Bull. Am. Ceram. Soc. 1988, 67, 392.

[25] Buresch, F. E. "Fracture Mechanics Applied to Brittle Materials", Edited by Freiman S. W. ASTM STP 675", 1979, 151. 